\title{
Origins and molecular biology of testicular germ cell tumors
}

\author{
Victor E Reuter \\ Department of Pathology, Memorial Sloan-Kettering Cancer Center, New York, NY, USA
}

\begin{abstract}
Testicular germ cell tumors can be divided into three groups (infantile/prepubertal, adolescent/young adult and spermatocytic seminoma), each with its own constellation of clinical histology, molecular and clinical features. They originate from germ cells at different stages of development. The most common testicular cancers arise in postpubertal men and are characterized genetically by having one or more copies of an isochromosome of the short arm of chromosome 12 [i(12p)] or other forms of $12 \mathrm{p}$ amplification and by aneuploidy. The consistent gain of genetic material from chromosome 12 seen in these tumors suggests that it has a crucial role in their development. Intratubular germ cell neoplasia, unclassified type (IGCNU) is the precursor to these invasive tumors. Several factors have been associated with their pathogenesis, including cryptorchidism, elevated estrogens in utero and gonadal dysgenesis. Tumors arising in prepubertal gonads are either teratomas or yolk sac tumors, tend to be diploid and are not associated with i(12p) or with IGCNU. Spermatocytic seminoma (SS) arises in older patients. These benign tumors may be either diploid or aneuploid and have losses of chromosome 9 rather than $\mathrm{i}(12 \mathrm{p})$. Intratubular SS is commonly encountered but IGCNU is not. The pathogenesis of prepubertal GCT and SS is poorly understood.
\end{abstract}

Modern Pathology (2005) 18, S51-S60. doi:10.1038/modpathol.3800309

Keywords: germ cell tumors; pathogenesis; intratubular germ cell neoplasia; molecular genetics

\section{Incidence}

Germ cell tumors are a heterogeneous group of neoplasms that arise primarily in the gonads and rarely from specific extragonadal sites along the midline, the pineal gland, mediastinum, retroperitoneum and sacrum. This particular distribution is thought to be due to the migration route of the primordial germ cells to the genital ridge. ${ }^{1-3}$ Testicular germ cell tumors (TGCT) comprise approximately $98 \%$ of all testicular neoplasms and are the most common malignancy in males between the ages of 15 and 35 years. ${ }^{4}$

It is possible to define three epidemiologically, clinically and histologically diverse groups of testicular germ cell tumors (Table 1). ${ }^{1}$ The first group includes teratomas and yolk sac tumors of neonates and infants. These tumors occur well before puberty and have an annual incidence of approximately 0.12 per 100000 . The second group includes seminomas and nonseminomatous germ cell tumors in postpubertal patients, by far the most

Correspondence: Dr VE Reuter, MD, Department of Pathology, Memorial Sloan-Kettering Cancer Center, 1275 York Avenue, New York, NY 10021, USA.

E-mail: reuterv@mskcc.org

Received and accepted 29 August 2004 common form of TGCT, with an incidence of approximately 6.0 per 100000 per year and occurring usually between 15 and 40 years of age. The peak incidence for seminomas is in the fourth decade while for nonseminomas it is a decade earlier. The final group is spermatocytic seminoma, which usually occurs in an older age group and has an annual incidence of approximately 0.2 per 100000.

It is clear that the incidence of TGCTs varies with geographic location and race (Table 2). ${ }^{5-7}$ The highest incidence reported is from Scandinavia and Switzerland with an annual rate of over nine cases per 100000 males. Significantly lower rates have been reported from other locations such as Asia and Latin America. Evidence that race plays a role in this disease is provided by the fact that the incidence is over five times greater in Caucasian Americans compared to African Americans. ${ }^{8}$ The only nonwhite population with a relatively high incidence of TGCT is the Maoris of New Zealand. ${ }^{9}$

Interestingly, the incidence of TGCT in many countries has increased significantly during the last century. ${ }^{8,10-12}$ Based on SEER data, McGlynn and collaborators reported an overall rise of $44 \%$ in the incidence in the United States from 1973 to 1998, from 3.35 per 100000 men to 4.84 per 100000 . Although the rates increased among both white and 
Table 1 Testicular germ cell tumors

\begin{tabular}{|c|c|c|c|c|}
\hline Age & Histology & Incidence (per 100000 population) & Genetic abnormalities & Ploidy \\
\hline Prepubertal & Teratoma/YST & 0.12 & $-1 p,-6 q$ & $\begin{array}{l}\text { Teratoma: diploid } \\
\text { YST: aneuploid }\end{array}$ \\
\hline Postpubertal & Seminoma/nonseminoma & 6.0 & $\begin{array}{l}\text { IGCNU: } \pm \mathrm{i}(12 p) \\
\text { Seminomai: (12p) } \\
\text { Nonseminoma: } \mathrm{i}(12 \mathrm{p})\end{array}$ & $\begin{array}{l}\text { IGCNU: hypertriploid } \\
\text { Seminoma: hypertriploid } \\
\text { Nonseminoma: hypotriploid }\end{array}$ \\
\hline Older ( $>40$ years) & Spermatocytic seminoma & 0.2 & +9 & Tetraploid/diploid \\
\hline
\end{tabular}

YST $=$ Yolk sac tumor; IGCNU = intratubular germ cell neoplasia, unclassified type

Table 2 Factors implicated in the pathogenesis of TGCT

\begin{tabular}{ll}
\hline & Race \\
- & Familial/genetic predisposition \\
Socioeconomic class/occupation \\
- & Infertility \\
- & High levels of maternal estrogens \\
- & Low and high birth weights \\
- & Neonatal jaundice \\
- & Androgen insensitivity syndrome \\
\hline
\end{tabular}

black males, the increases observed were different in each group. Among white males, the incidence rose $52 \%$ (from 3.69 to 5.62 per 100000 ) whereas among black males the incidence rose $25 \%$ (from 0.83 to 1.04 per 100000$)$. An unexpected finding was that the increase differed among histologic groups. Although the overall incidence of seminoma increased $72 \%$ in white and $42 \%$ in black males, the increase in non-seminoma for white males was only $32 \%$ while in black males there was a modest decrease of $3.0 \%$. Most investigators have concluded that this increase in overall incidence of TGCT is due to changes in exposure to etiologic factors.

\section{Pathogenesis}

The relative importance of susceptibility genes vs environmental factors in the etiology of TGCT is a source of great debate among investigators. ${ }^{2,13-20}$ While both factors seem to play a role in this disease, at present their relative importance is not clear. We have previously mentioned differences among races. Some investigators have suggested a higher incidence among professionals and higher socioeconomic classes, but it is hard to evaluate the effect of race on these findings (Table 2). Some reports have suggested that specific occupations are associated with an increased risk but the data are conflicting and poorly controlled for confounding factors. Infertility has been associated with an increased risk of TGCT with intratubular germ cell neoplasia, unclassified type (IGCNU) being identified in $1-2 \%$ of cases. Nevertheless, infertility is itself associated with other conditions linked to the genesis of TGCT such as cryptorchidism and gonadal dysgenesis. Thus its importance as an independent risk factor is still in doubt.

Much stronger associations with the development of TGCT exist with factors such as exposure to high levels of maternal estrogen during pregnancy, neonatal jaundice and low and high birth weights. These findings suggest that the initiating events that lead to tumor development occur early, possibly during the prenatal period. ${ }^{19-23}$

The most widely accepted risk factor for TGCT is cryptorchidism, ${ }^{24,25}$ approximately $10 \%$ of the cases having this association. Cryptorchid patients have a four-fold elevated risk of developing TGCT, whether the cryptorchidism was corrected or not. ${ }^{26-28}$ There is some evidence that testicular maldescent is associated with prenatal exposure to estrogens. As a result of the elevated risk of germ cell neoplasia in cryptorchid gonads, some have suggested performing testicular biopsies in an attempt to identify IGCNU, which has been reported in up to $4 \%$ of cases.

Patients with a history of TGCT have an increased incidence of contralateral disease. The reported incidence varies between 2 and $5 \%$, the higher percentage having been reported from Scandinavian countries. ${ }^{29-31}$ The incidence is also higher if the contralateral testis is atrophic or maldescended. Other investigators have suggested that bilateral disease is more common in patients with a positive family history for TGCT and if the first tumor occurred at an early age. ${ }^{32}$ Bilateral tumors may develop synchronously or metachronously with approximately $50 \%$ occurring within 5 years. Some clinicians advocate biopsies of the contralateral gonad to identify IGCNU, which reliably predicts the subsequent development of an invasive GCT.

Some testicular tumors appear to be familial with approximately $2 \%$ of patients having an affected family member. ${ }^{32-36}$ These susceptible families rarely have more than two affected members and these are usually siblings rather than father and son. Early onset of disease and bilaterality are more common in this group of patients, with a reported frequency of $8-14 \%$.

Patients with various intersex syndromes are at increased risk for the development of TGCT. ${ }^{37-42}$ 
Patients with androgen insensitivity syndrome (testicular feminization) have a $5-10 \%$ risk of developing GCT, usually after the complete development of secondary female sexual characteristics. Gonadal dysgenesis in patients who carry a Y chromosome is a significant risk factor for germ cell tumor development. Linkage studies by Chemes et $a l^{43}$ have shown a strong correlation between the presence of the Y chromosome and the severity of the gonadal dysgenesis. Gonadoblastoma acts as an 'in situ' precursor in these patients. Recently, Skakkebaek and co-workers ${ }^{37,42}$ suggested that many patients with testicular GCT have some evidence of gonadal dysgenesis in the contralateral gonad, be it microlithiasis, Sertoli-cell-only tubules, seminiferous tubules with undifferentiated Sertoli cells or IGCNU. If this is true, it suggests that a specific genetic mutation may not be required to initiate the process of tumor development, but rather environmental factors are sufficient as initiating events. Testicular biopsies in at-risk patients with intersex syndromes may aid in identifying IGCNU.

\section{Intratubular germ cell neoplasia}

This term refers to the lesion initially described by Skakkebaek as 'carcinoma in situ' as well as to other 'differentiated' forms of intratubular germ cell neoplasia. ${ }^{44-47}$ Strictly speaking, the lesion originally described by Skakkebaek is now called 'intratubular germ cell neoplasia, unclassified' by most, at least in the Western Hemisphere.

The story of testicular 'carcinoma in situ'/intratubular germ cell neoplasia is fascinating and serves as a paradigm for the concept of progression from incipient or preinvasive neoplasia to invasive disease. ${ }^{46,48}$ In 1972, Skakkebaek reported 'atypical spermatogonia' in two men undergoing testicular biopsies during the work-up for infertility, who subsequently developed invasive TGCT. He hypothesized that these cells constituted 'carcinoma in situ'. Two subsequent seminal studies by his group proved that this was indeed the case. In 1978, he reported a series of 555 men who underwent testicular biopsies for infertility. ${ }^{48}$ They identified six patients with evidence of 'carcinoma in situ'. With a median follow-up period of approximately 3 years, three of these patients developed evidence of an invasive germ cell tumor; one of them with bilateral disease. The remaining 449 patients were tumor free during the same follow-up period.

In 1986, the Skakkebaek group reported their experience with contralateral biopsies in 500 patients with unilateral GCT. ${ }^{49}$ A total of 27 patients $(5.4 \%)$ were found to have 'carcinoma in situ'. Eight patients received systemic chemotherapy for advanced disease. Of the remaining 19 patients, seven $(37 \%)$ developed invasive GCT at this site within the follow-up period. Mathematical modeling suggested that $50 \%$ of biopsy-positive cases would develop disease within 5 years. Remarkably, not a single case of contralateral GCT developed in the remaining 463 biopsy-negative patients during the same follow-up period. In a subsequent report, the authors revealed that at least two of the biopsy-positive cases that received systemic therapy subsequently developed contralateral tumors, suggesting that systemic therapy is not always effective against preinvasive disease. ${ }^{50}$

It is clear that the original lesion described by Skakkebaek is the precursor to all types of germ cell tumors, at least for those that originate in postpubertal gonads, other than spermatocytic seminoma. In early 1980, a group of distinguished pathologists, including Drs Robert Scully, Juan Rosai, FKK Mostofi and Robert Kurman, met in Minnesota to discuss nomenclature of incipient germ cell neoplasia. They agreed that 'carcinoma in situ' was a less than optimal choice to describe this lesion since it had no features of epithelial differentiation. They suggested the term 'intratubular germ cell neoplasia, unclassified' (IGCNU) because it was associated with all morphologic types of GCT with the exception of spermatocytic seminoma. It also underscores the fact that differentiated forms of intratubular germ cell neoplasia may occur, including intratubular embryonal carcinoma.

IGCNU can be seen adjacent to invasive germ cell tumors in virtually all cases in which residual testicular parenchyma is present. ${ }^{44,51}$ As previously mentioned, it is present in up to $4 \%$ of cryptorchid patients, in up to $5 \%$ of contralateral gonads in patients with unilateral GCT and in up to $1 \%$ of patients biopsied for oligospermic infertility. Its association with TCGT arising in prepubertal patients is still a source of controversy. ${ }^{1,52,53}$ While some authors suggest that it does not occur, others state that it does. In either case, we can state with reasonable certainty that, if IGCNU does occur in childhood tumors, it is certainly less apparent.

IGCNU is characterized morphologically by the presence of enlarged, atypical germ cells located immediately above a usually irregularly thickened basement membrane (Figure 1). The atypical cells are either isolated or form a single row along the basement membrane. They are typically larger than spermatogonia, the other cell that usually resides near the basement membrane. IGCNU cells have clear cytoplasm, irregular nuclear contours, coarse chromatin, and enlarged nucleoli, which may be single or multiple. On the other hand, spermatogonia may also have clear cytoplasm but the cells are small, have round and regular nuclear contours, densely packed chromatin and no nucleoli. In most cases, tumor-bearing tubules do not have active spermatogenesis and contain mostly Sertoli cells. Sertoli cells may be displaced towards the tubular lumen. Characteristically they contain a single nucleolus which is small and regular. The nuclei 

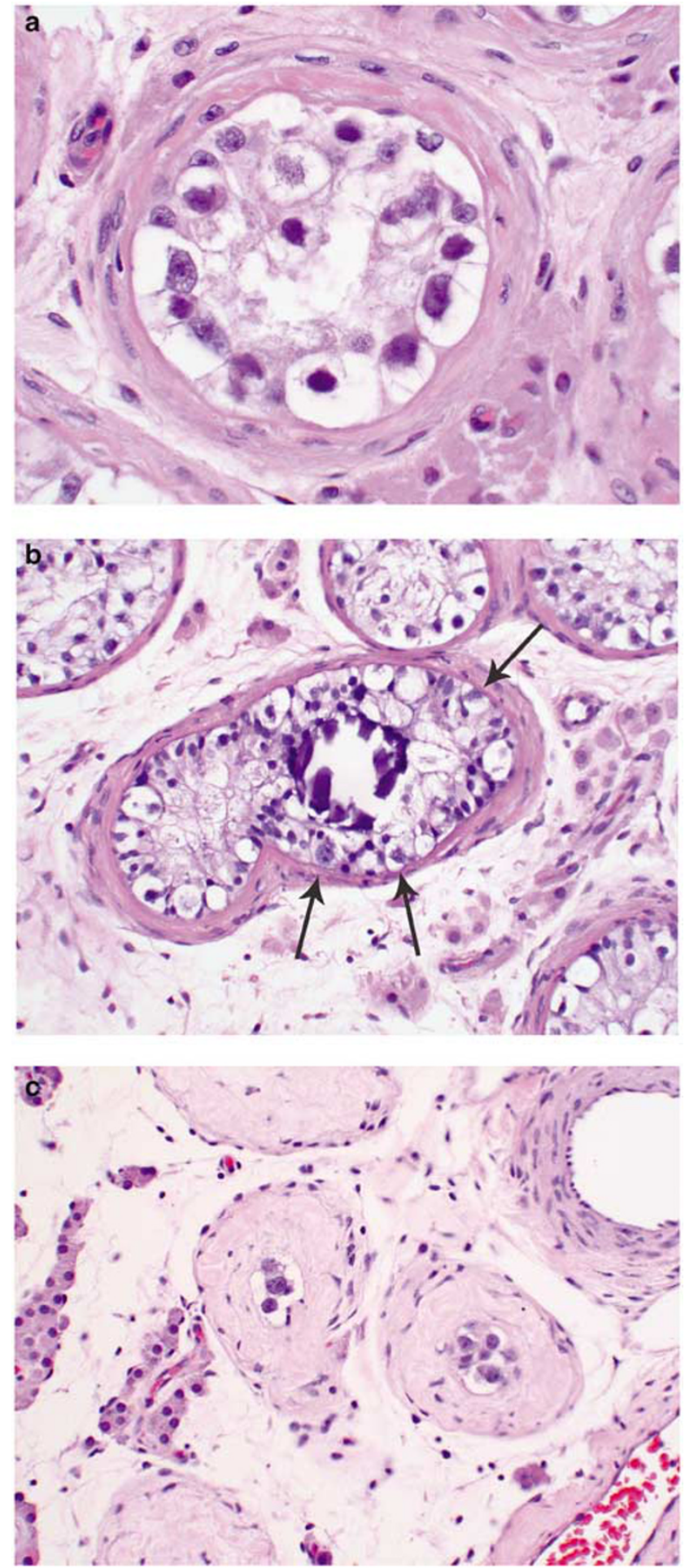

Figure 1 (a) IGCNU. The malignant cells are located towards the periphery of the lumen. They exhibit cytoplasmic clearing and the nuclei are enlarged, have irregular contours, coarse chromatin and prominent nucleoli. (b) IGCNU (arrows) associated with microlithiasis. (c) Isolated neoplastic cells (IGCNU) within hyalinized tubules.

are oval or round with regular borders and the chromatin is fine. The cytoplasm is amphophilic/ eosinophilic and not vacuolated.

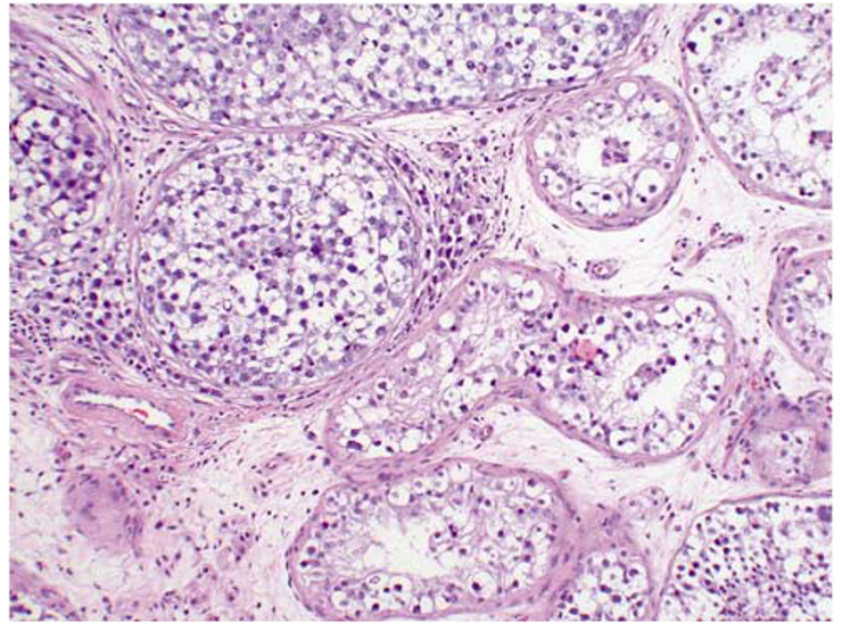

Figure 2 Intratubular seminoma. The seminiferous tubules are filled with tumor cells cytologically indistinguishable from IGCNU, the latter evident at the right.

In essence, the cytologic features of classic IGCNU are those of seminoma. The relationship is supported by the coexpression of a host of histochemical and immunohistochemical markers among both cell types. Further evidence comes from electron microscopy, which has shown that both share common ultrastructural features including the absence of well-developed cytoplasmic intermediate filaments, inconspicuous organelles, glycogen particles, lack of mature desmosomes and cell junctions, and nucleoli with ropy nucleolonema. Tubules whose lumen are filled with these cells may be regarded as 'intratubular seminoma' (Figure 2).

IGCNU may extend into the rete testis, usually undermining the epithelium in a 'pagetoid' pattern (Figure 3a). At times the epithelium may become hyperplastic and in this setting it is important not to confuse this finding with the presence of nonseminomatous germ cell tumor (Figure $3 b$ ).

IGCNU cells contain glycogen and thus are PASpositive, diastase-sensitive. Rarely will other intratubular cells, either spermatogonia or Sertoli cells, show similar positivity. Placental-like alkaline phosphatase (PLAP) is one of the isoforms of alkaline phosphatase. PLAP antibodies will stain IGCNU and the majority of seminomas and embryonal carcinomas as well as a smaller percentage of yolk sac tumors. Immunoreactivity is seen in virtually all cases of IGCNU and the staining pattern is usually membranous or cytoplasmic (Figure 4a). No other non-neoplastic intratubular cells are immunoreactive for PLAP, but immunoreactivity may be seen in other types of nongerm cell malignancies. ${ }^{54-57}$ C-kit (CD 117) is expressed in a large percentage of IGCNU as well as seminomas, but not in other germ cell tumors. ${ }^{58}$ Once again, the staining pattern is cytoplasmic/membranous (Figure 4b). Despite the overexpression of this antigen, c-kit is rarely mutated in these tumors. Other antibodies, 

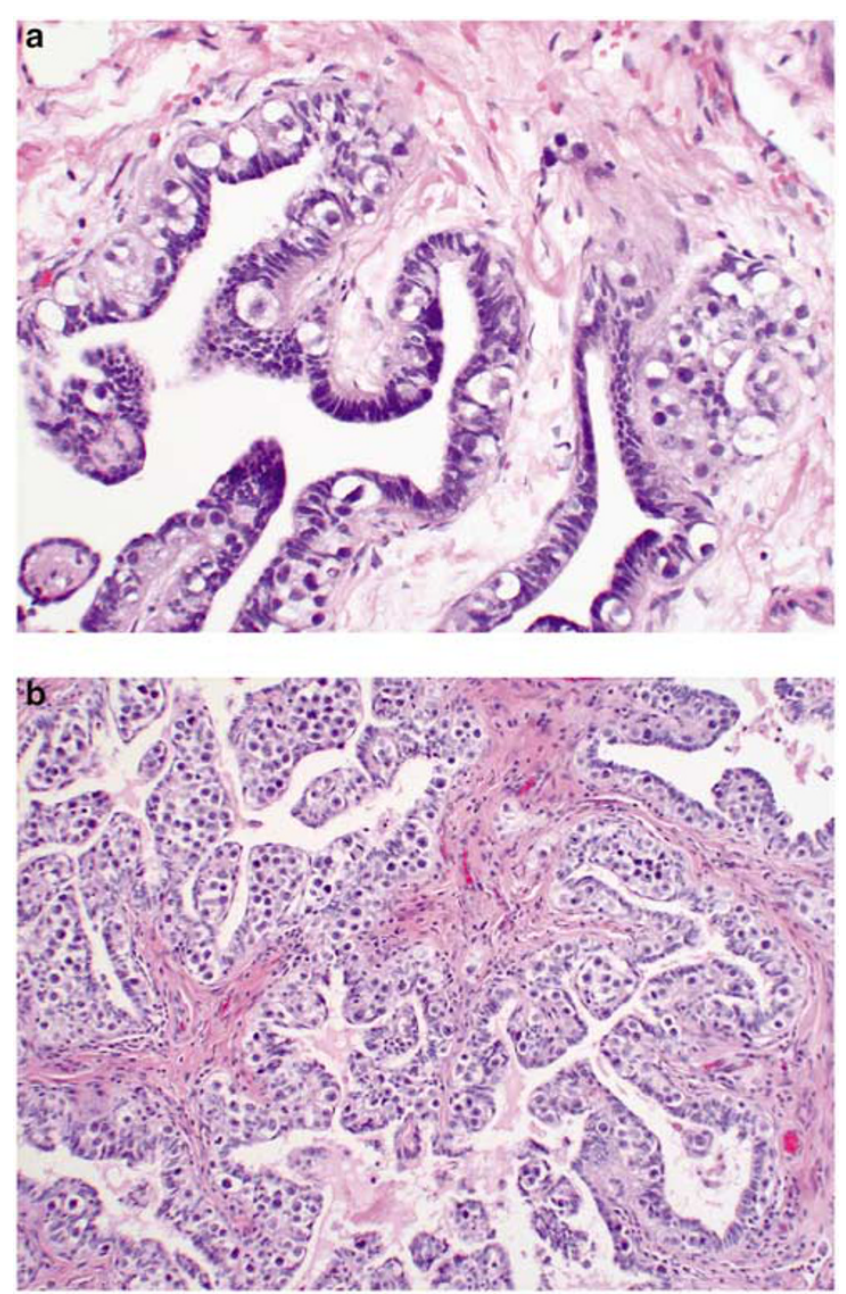

Figure 3 (a) Pagetoid extension of IGCNU into the rete testis. (b) Pagetoid extension of IGCNU into the rete testis associated with reactive hyperplasia of the rete epithelium. This finding may be confused with nonseminomatous GCT.

which immunoreact with IGCNU but are rarely used in clinical practice, include $\mathrm{M} 2 \mathrm{~A}$ and $43-\mathrm{F}^{.57,59,60}$ POU5F1 (Oct3/4) is a very interesting marker that was recently described. ${ }^{61}$ The gene serves as a transcription factor and its product is expressed in pluripotent mouse and human embryonic stem cells and is downregulated during differentiation. Since the gene is also required for self-renewal of embryonic stem cells, knocking out the gene is lethal. Early reports suggest that this antigen is expressed solely in IGCNU, seminoma and embryonal carcinoma, suggesting that these are the types of GCT cells with pluripotency, that is, with capacity to differentiate. In any event, it provides us with yet another marker for IGCNU (Figure 4c).

It is important to keep in mind that the presence of neoplastic cells within tubules does not always constitute IGCNU and that one must adhere strictly to the established diagnostic criteria. Other forms of intratubular germ cell neoplasia (IGCN) include intratubular seminoma (Figure 2), intratubular em-
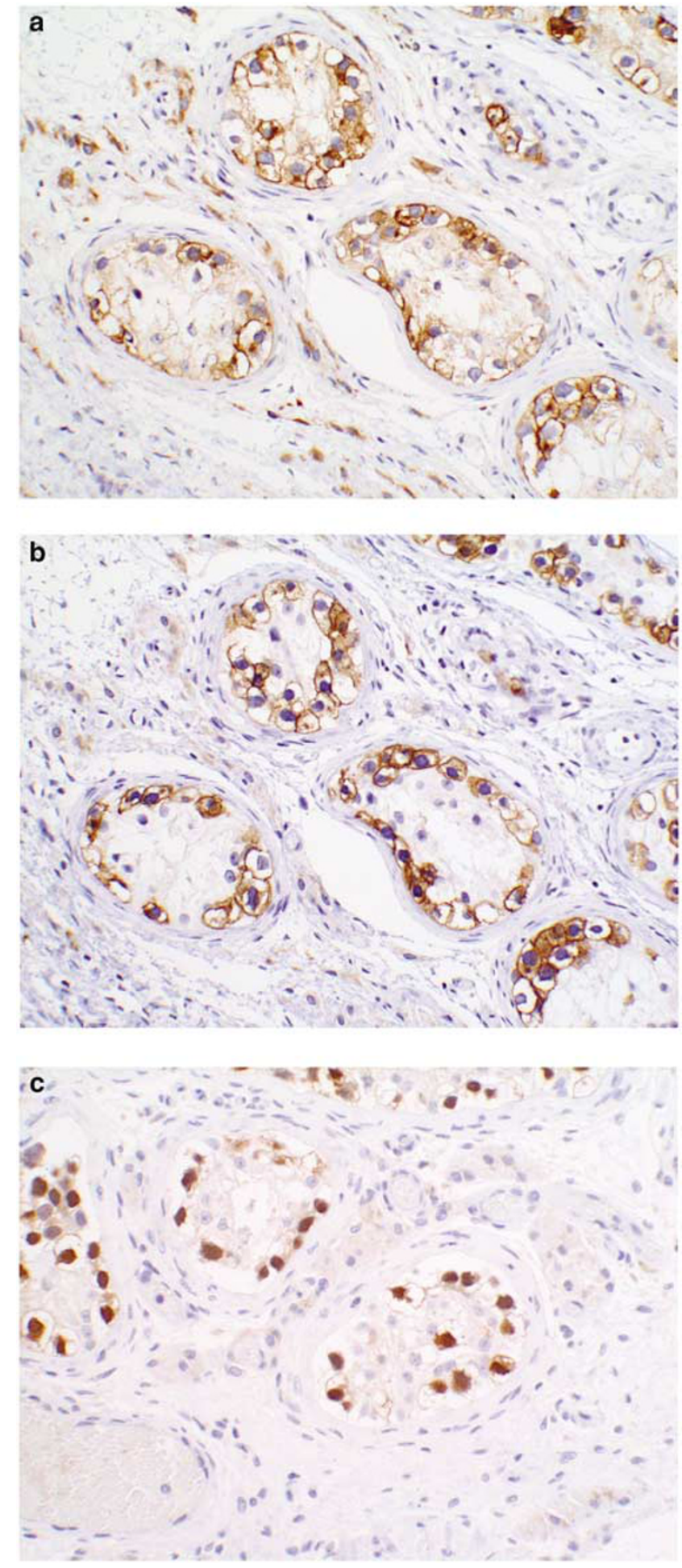

Figure 4 Immunoreactivity in IGCNU. (a) Placental-like alkaline phosphatase. (b) CD-117 (c-kit). Note cytoplasmic staining with accentuation of the cytoplasmic membrane with both markers. (c) Oct3/4. Strong nuclear immunoreactivity is limited to the neoplastic cells.

bryonal carcinoma (Figure 5) and intratubular spermatocytic seminoma (Figure 6). Secondary tumors may sometimes grow within the seminiferous tubules and mimic IGCN, including melanoma 
S56

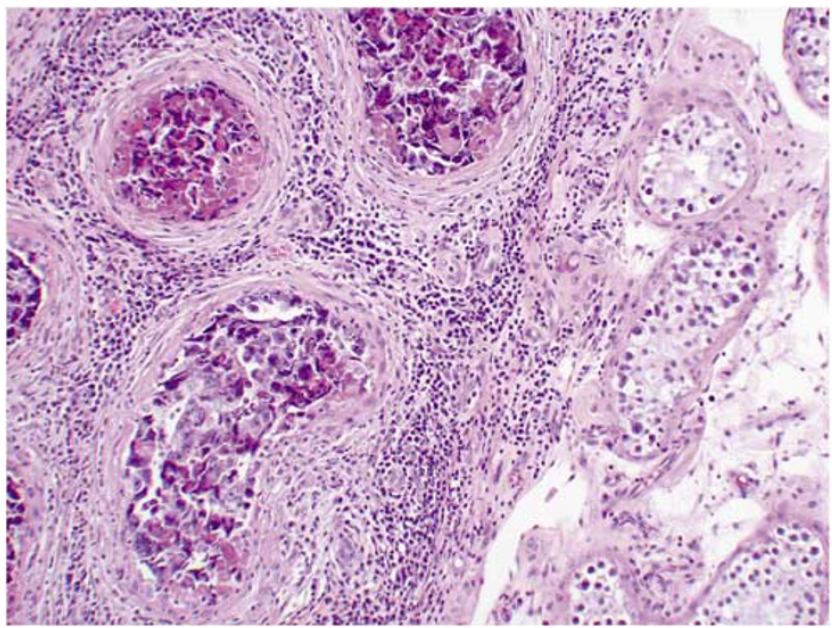

Figure 5 Intratubular embryonal carcinoma. The tumor cells are cytologically high grade and demonstrate comedo-type necrosis. A fibroinflammatory reaction characteristically surrounds the effected tubules.

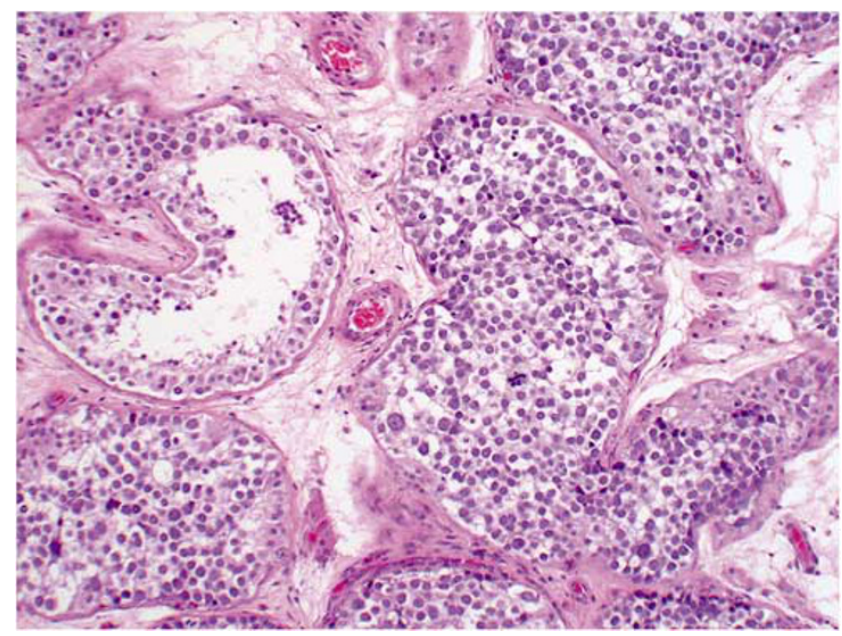

Figure 6 Intratubular spermatocytic seminoma. The tubules are distended by a polymorphous population of cells and lack the characteristic features of IGCNU.

(Figure 7), prostatic carcinoma, lymphoma and even mesothelioma.

\section{Molecular biology of germ cell tumors}

The molecular biology of GCTs is fascinating and fertile ground for basic and translational research. As GCTs are for the most part curable due to effective chemotherapy and in some cases by surgery alone, lessons learned from this disease may help treat other solid tumors more effectively.

The initiating genetic events that lead to IGCNU and subsequent invasive GCT have yet to be agreed upon. ${ }^{1,2,13,62-64}$ There are two major theories, the first being championed by Chaganti and Houldsworth. ${ }^{63,64}$ They have postulated that the most likely

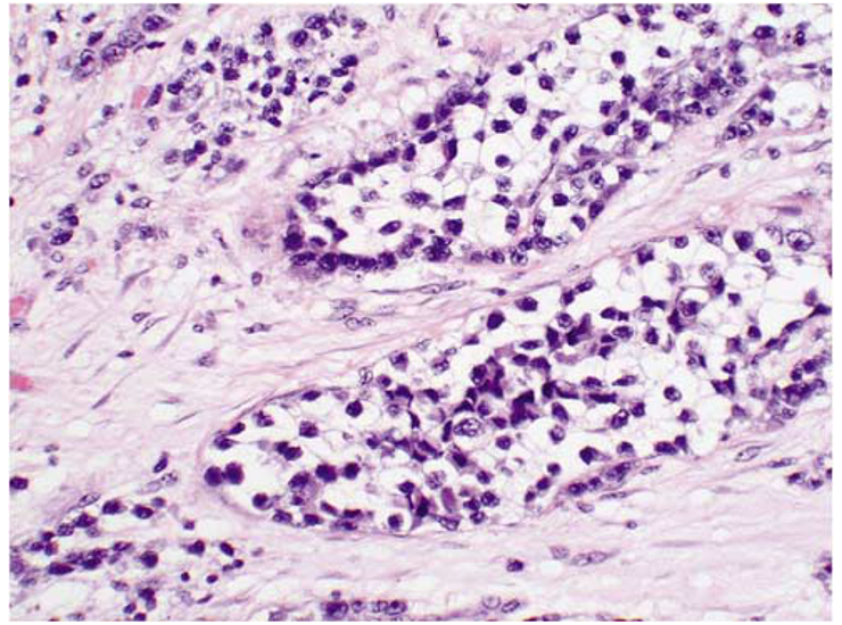

Figure 7 Intratubular metastatic melanoma. This lesion could be confused with intratubular seminoma in the absence of the clinical history, although greater nuclear variability represents a subtle clue.

target cell for transformation is the zygotene-pachytene spermatocyte where there appears to be a 'recombination checkpoint'. At this stage, there is replicated DNA and upregulated p53, the latter to allow prolongation of the phase and recombination. If unresolved, DNA strand breaks occur and the elevated wild-type p53 can provide an apoptotic trigger. In this model, aberrant chromatid exchange events associated with crossing-over may lead to increased $12 \mathrm{p}$ copy number. Possibly through the oncogenic effect of cyclin D2, this aberrant, genomically unstable cell is now able to escape the apoptotic effects of p53 and may re-enter the cell cycle, now as a neoplastic cell.

A second and more widely accepted hypothesis is promulgated by Skakkebaek and others. ${ }^{14,62,65}$ This model suggests that fetal gonocytes (primordial germ cells) may undergo abnormal cell division (polyploidization) due to mostly environmental factors in utero and give rise to IGCNU. Polyploidization precedes the formation of $i(12 p)$. These cells are now susceptible to postnatal and pubertal gonadotropin stimulation and the development of invasive tumors. This hypothesis is based primarily on immunohistochemical data linking gonocytes to IGCNU, developmental abnormalities associated with GCT and epidemiological data.

Once again I must emphasize that there are three distinct categories of testicular GCT, each with its own clinical, pathologic and genetic characteristics. Most of what is known about the genetics of this tumor deals with the most common type, those that arise in adolescents and young adults. Seminomas and nonseminomas that arise in this group are consistently aneuploid. The median DNA content of IGCNU and seminoma is hypertriploid and that of nonseminomas is hypotriploid. The characteristic genetic abnormality of these tumors is excess genetic material of the short arm of chromosome 
12 , usually in the form of an isochromosome; $i(12 p)$ (Figure 8). This genetic abnormality occurs in all primary sites and histologic types. ${ }^{66,67}$ Approximately $80 \%$ of cases have $\mathrm{i}(12 \mathrm{p})$ and the remainder have excess $12 \mathrm{p}$ genetic material in derivative chromosomes. ${ }^{68}$ The consistent gain of $12 \mathrm{p}$ genetic material is supported by gene array and comparative genomic hybridization data. ${ }^{69,70}$ The presence of $\mathrm{i}(12 \mathrm{p})$ in IGCNU is a matter of controversy with most investigators suggesting it is not present. ${ }^{2,14}$ This finding tends to support the Skakkebaek hypothesis that polyploidization is an initiating event followed by $\mathrm{i}(12 \mathrm{p})$ in the invasive phenotype. Since the formation of the isochromosome includes the centromeric/pericentromeric region of chromosome 12 , the abnormality can be detected using commercially available chromosome 12 centromeric fluorescent in situ hybridization (FISH) probes. ${ }^{67,68,71}$ In a metaphase spread these will show the isochromosome nicely. In interphase cells one can detect a numerical abnormality (normal chromosome 12 plus the number of isochromosomes present) but it is more difficult if not impossible to state that an isochromosome is indeed present. On the other hand, a library probe of the short arm of chromosome 12 can highlight the presence of the isochromosome more easily in metaphase spreads as well as in resting cells (Figure 9).

Data suggest that the consistent gain of genetic material from chromosome 12 is crucial for the development of an invasive GCT resulting in efforts to identify the specific genes involved. Some investigators have identified an amplified region at 12p11.2-12.1. Several genes of interest are located in this region including $S O X 5, J A W 1$ and $K-R A S .{ }^{14}$ More recent data suggest that this minimally deleted region applies preferentially to seminomas, suggesting that the search for putative relevant genes should not be restricted to this region. For example, Houldsworth et $\mathrm{al}^{72}$ implicated cyclin D2, which is mapped to region $12 \mathrm{p} 13$, as the most likely gene to be involved. To date, 247 transcripts mapped to $12 \mathrm{p}$ have been evaluated for expression using microarray technology and 24 were found to be overexpressed

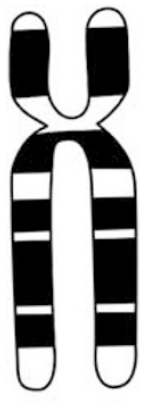

12

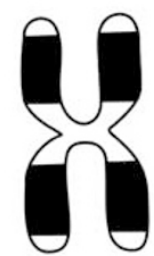

\section{i(12p)}

Figure 8 Diagram of chromosome 12 and isochromosome 12p. The image on the right shows an $\mathrm{i}(12 \mathrm{p})$ as seen in a karyotype.

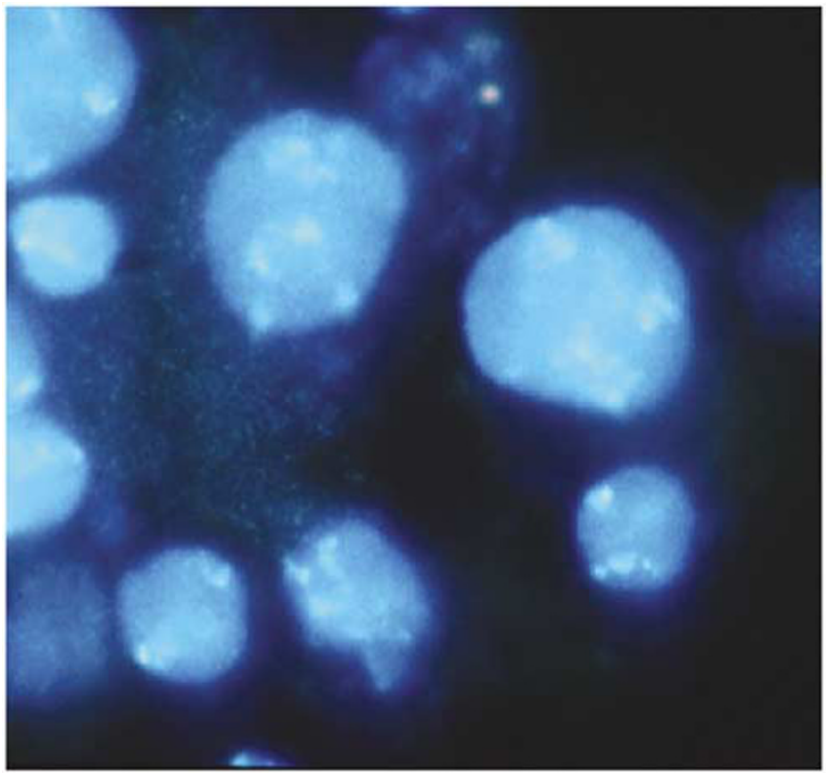

Figure 9 FISH using a $12 \mathrm{p}$ specific probe. The large, irregular signals are indicative of the presence of excess genetic material from the short arm of chromosome 12 .

in over $70 \%$ of tumor samples relative to normal testis. A significant number of these transcripts are located telomeric to the 12p11-12p12 region.

A few studies have suggested the presence of relevant tumor suppressor genes but the data have not been consistent. Murty et $a l^{73}$ described two regions of interest on chromosome 12 (q13 and q22) although no candidate genes have been proposed. Homozygous deletions in the region of $D C C$ on $18 \mathrm{q}$ have also been identified and associated to progression. Extensive molecular analyses have identified genomic and/or functional (expression) loss of several other known tumor suppressor genes such as $R B 1, N M E, W T 1, A P C$, and $p 16$ although no consistent, reproducible and mechanistic data are available to date linking these genes with tumor development or progression. ${ }^{2,14}$ Mutation of the p53 gene is a rare event in GCT, yet a few investigators have suggested mutation of this gene in some chemotherapy-resistant tumors. ${ }^{74}$ Whether this mutation is responsible for chemoresistance rather than an epiphenomenon has not been resolved.

As previously mentioned, GCTs in infants and adults are genetically distinct. ${ }^{1,2,75-80}$ While virtually all adult cases are aneuploid, pediatric cases are mostly diploid, particularly teratomas, although yolk sac tumors may be nondiploid. Imprinting studies suggest that both arise from primordial germ cells but at a different stage of germ cell development. ${ }^{76}$ It is quite likely that initiation of childhood GCT occurs during germ cell migration to the genital ridge while this step takes place at a later stage in adults. i(12p) and 12p amplification are rare events in pediatric tumors. Bussey et $a l^{77}$ found that $12 \mathrm{p}$ amplification in childhood GCT was age dependent 
and only seen in patients above the age of 9 years. On the other hand, pediatric tumors are characterized by deletions of $1 p$, particularly region $p 36$, loss of 6q, and structural abnormalities of chromosome 2 and 3p. Published reports point towards a significant heterogeneity in the structural chromosomal constitution of infantile teratomas. Genetic studies on spermatocytic seminoma are few; it appears that the most common chromosomal abnormality is gains in chromosome $9 .^{2} \mathrm{~A}$ combined immunohistochemical and molecular study by Stoop et $a l^{81}$ supports that these tumors are likely to originate in a cell farther along the developmental pathway than those that give rise to other germ cell tumors.

\section{References}

1 Looijenga LH, Oosterhuis JW. Pathogenesis of testicular germ cell tumours. Rev Reprod 1999;4:90-100.

2 Oosterhuis JW, Looijenga LH. Current views on the pathogenesis of testicular germ cell tumours and perspectives for future research: highlights of the 5th Copenhagen Workshop on Carcinoma in situ and Cancer of the Testis. Apmis 2003;111:280-289.

3 Slowikowska-Hilczer J, Romer TE, Kula K. Neoplastic potential of germ cells in relation to disturbances of gonadal organogenesis and changes in karyotype. J Androl 2003;24:270-278.

4 Bosl GJ, Motzer RJ. Testicular germ-cell cancer. N Engl J Med 1997;337:242-253.

5 Moller H. Trends in incidence of testicular cancer and prostate cancer in Denmark. Hum Reprod 2001;16: 1007-1011.

6 Bergstrom R, Adami HO, Mohner M, et al. Increase in testicular cancer incidence in six European countries: a birth cohort phenomenon. J Natl Cancer Inst 1996;88:727-733.

7 Adami HO, Bergstrom R, Mohner M, et al. Testicular cancer in nine northern European countries. Int J Cancer 1994;59:33-38.

8 McGlynn KA, Devesa SS, Sigurdson AJ, et al. Trends in the incidence of testicular germ cell tumors in the United States. Cancer 2003;97:63-70.

9 Wilkinson TJ, Colls BM, Schluter PJ. Increased incidence of germ cell testicular cancer in New Zealand Maoris. Br J Cancer 1992;65:769-771.

10 Stone JM, Cruickshank DG, Sandeman TF, et al. Trebling of the incidence of testicular cancer in victoria, Australia (1950-1985). Cancer 1991;68:211-219.

11 Boyle P, Kaye SB, Robertson AG. Changes in testicular cancer in Scotland. Eur J Cancer Clin Oncol 1987;23: 827-830.

12 Power DA, Brown RS, Brock CS, et al. Trends in testicular carcinoma in England and Wales, 1971-99. Br J Urol Int 2001;87:361-365.

13 Looijenga LH, Oosterhuis JW. Pathobiology of testicular germ cell tumors: views and news. Anal Quant Cytol Histol 2002;24:263-279.

14 Skotheim RI, Lothe RA. The testicular germ cell tumour genome. Apmis 2003;111:136-150; discussion 50-51.

15 Forman D, Gallagher R, Moller H, et al. Aetiology and epidemiology of testicular cancer: report of consensus group. Prog Clin Biol Res 1990;357:245-253.
16 Swerdlow AJ. The epidemiology of testicular cancer. Eur Urol 1993;23(Suppl 2):35-38.

17 Hardell L, Nasman A, Ohlson CG, et al. Case-control study on risk factors for testicular cancer. Int J Oncol 1998;13:1299-1303.

18 Coupland CA, Chilvers CE, Davey G, et al. Risk factors for testicular germ cell tumours by histological tumour type. United Kingdom Testicular Cancer Study Group. Br J Cancer 1999;80:1859-1863.

19 Richiardi L, Akre O, Bellocco R, et al. Perinatal determinants of germ-cell testicular cancer in relation to histological subtypes. Br J Cancer 2002;87:545-550.

20 Richiardi L, Askling J, Granath F, et al. Body size at birth and adulthood and the risk for germ-cell testicular cancer. Cancer Epidemiol Biomarkers Prev 2003;12:669-673.

21 Ekbom A. Growing evidence that several human cancers may originate in utero. Semin Cancer Biol 1998;8:237-244.

22 Ekbom A, Akre O. Increasing incidence of testicular cancer-birth cohort effects. Apmis 1998;106:225-229; discussion 229-231.

23 Depue RH, Pike MC, Henderson BE. Estrogen exposure during gestation and risk of testicular cancer. J Natl Cancer Inst 1983;71:1151-1155.

24 Halme A, Kellokumpu-Lehtinen P, Lehtonen T, et al. Morphology of testicular germ cell tumours in treated and untreated cryptorchidism. Br J Urol 1989;64: 78-83.

25 Schottenfeld D, Warshauer ME, Sherlock S, et al. The epidemiology of testicular cancer in young adults. Am J Epidemiol 1980;112:232-246.

26 Pike MC, Chilvers C, Peckham MJ. Effect of age at orchidopexy on risk of testicular cancer. Lancet 1986;1:1246-1248.

27 Pottern LM, Brown LM, Hoover RN, et al. Testicular cancer risk among young men: role of cryptorchidism and inguinal hernia. J Natl Cancer Inst 1985;74: $377-381$.

28 Giwercman A, Grindsted J, Hansen B, et al. Testicular cancer risk in boys with maldescended testis: a cohort study. J Urol 1987;138:1214-1216.

29 Dieckmann KP, Loy V, Buttner P. Prevalence of bilateral testicular germ cell tumours and early detection based on contralateral testicular intra-epithelial neoplasia. $\mathrm{Br}$ J Urol 1993;71:340-345.

30 Dieckmann KP, Loy V. The value of the biopsy of the contralateral testis in patients with testicular germ cell cancer: the recent German experience. Apmis 1998;106:13-20; discussion 20-23.

31 Osterlind A, Berthelsen JG, Abildgaard $\mathrm{N}$, et al. Incidence of bilateral testicular germ cell cancer in Denmark, 1960-84: preliminary findings. Int J Androl 1987;10:203-208.

32 Lutke Holzik MF, Sijmons RH, Sleijfer DT, et al. Syndromic aspects of testicular carcinoma. Cancer 2003;97:984-992.

33 Dieckmann KP, Becker T, Jonas D, et al. Inheritance and testicular cancer. Arguments based on a report of 3 cases and a review of the literature. Oncology 1987;44: $367-377$.

34 Classen J, Dieckmann KP, Loy V, et al. [Testicular intraepithelial neoplasms (TIN). An indication for radiotherapy?]. Strahlenther Onkol 1998;174:173-177.

35 Patel SR, Kvols LK, Richardson RL. Familial testicular cancer: report of six cases and review of the literature. Mayo Clin Proc 1990;65:804-808. 
36 Heimdal K, Olsson H, Tretli S, et al. Familial testicular cancer in Norway and southern Sweden. Br J Cancer 1996;73:964-969.

37 Skakkebaek NE, Holm M, Hoei-Hansen C, et al. Association between testicular dysgenesis syndrome (TDS) and testicular neoplasia: evidence from 20 adult patients with signs of maldevelopment of the testis. Apmis 2003;111:1-11.

38 Rutgers JL, Scully RE. Pathology of the testis in intersex syndromes. Semin Diagn Pathol 1987;4: 275-291.

39 Rutgers JL, Scully RE. The androgen insensitivity syndrome (testicular feminization): a clinicopathologic study of 43 cases. Int J Gynecol Pathol 1991;10: 126-144.

40 Collins GM, Kim DU, Logrono R, et al. Pure seminoma arising in androgen insensitivity syndrome (testicular feminization syndrome): a case report and review of the literature. Mod Pathol 1993;6:89-93.

41 Ramani P, Yeung CK, Habeebu SS. Testicular intratubular germ cell neoplasia in children and adolescents with intersex. Am J Surg Pathol 1993;17:1124-1133.

42 Hoei-Hansen CE, Holm M, Rajpert-De Meyts E, et al. Histological evidence of testicular dysgenesis in contralateral biopsies from 218 patients with testicular germ cell cancer. J Pathol 2003;200:370-374.

43 Chemes HE, Muzulin PM, Venara MC, et al. Early manifestations of testicular dysgenesis in children: pathological phenotypes, karyotype correlations and precursor stages of tumour development. Apmis 2003; 111:12-24.

44 Dieckmann KP, Skakkebaek NE. Carcinoma in situ of the testis: review of biological and clinical features. Int J Cancer 1999;83:815-822.

45 Montironi R. Intratubular germ cell neoplasia of the testis: testicular intraepithelial neoplasia. Eur Urol 2002;41:651-654.

46 Gondos B, Berthelsen JG, Skakkebaek NE. Intratubular germ cell neoplasia (carcinoma in situ): a preinvasive lesion of the testis. Ann Clin Lab Sci 1983;13:185-192.

47 Skakkebaek NE. Atypical germ cells in the adjacent 'normal' tissue of testicular tumours. Acta Pathol Microbiol Scand [A] 1975;83:127-130.

48 Skakkebaek NE. Carcinoma in situ of the testis: frequency and relationship to invasive germ cell tumours in infertile men. Histopathology 1978;2:157-170.

49 von der Maase H, Rorth M, Walbom-Jorgensen S, et al. Carcinoma in situ of contralateral testis in patients with testicular germ cell cancer: study of 27 cases in 500 patients. Br Med J (Clin Res Ed) 1986;293:13981401.

50 von der Maase $H$, Meinecke B, Skakkebaek NE. Residual carcinoma-in-situ of contralateral testis after chemotherapy. Lancet 1988;1:477-478.

51 Jacobsen GK, Henriksen OB, von der Maase $H$. Carcinoma in situ of testicular tissue adjacent to malignant germ-cell tumors: a study of 105 cases. Cancer 1981;47:2660-2662.

52 Manivel JC, Simonton S, Wold LE, et al. Absence of intratubular germ cell neoplasia in testicular yolk sac tumors in children. A histochemical and immunohistochemical study. Arch Pathol Lab Med 1988;112: 641-645.

$53 \mathrm{Hu}$ LM, Phillipson J, Barsky SH. Intratubular germ cell neoplasia in infantile yolk sac tumor. Verification by tandem repeat sequence in situ hybridization. Diagn Mol Pathol 1992;1:118-128.
54 Manivel JC, Jessurun J, Wick MR, et al. Placental alkaline phosphatase immunoreactivity in testicular germ-cell neoplasms. Am J Surg Pathol 1987;11:21-29.

55 Wick MR, Swanson PE, Manivel JC. Placental-like alkaline phosphatase reactivity in human tumors: an immunohistochemical study of 520 cases. Hum Pathol 1987;18:946-954.

56 Burke AP, Mostofi FK. Intratubular malignant germ cells in testicular biopsies: clinical course and identification by staining for placental alkaline phosphatase. Mod Pathol 1988;1:475-479.

57 Giwercman A, Cantell L, Marks A. Placental-like alkaline phosphatase as a marker of carcinoma-in-situ of the testis. Comparison with monoclonal antibodies M2A and 43-9F. Apmis 1991;99:586-594.

58 Leroy X, Augusto D, Leteurtre E, et al. CD30 and CD117 (c-kit) used in combination are useful for distinguishing embryonal carcinoma from seminoma. J Histochem Cytochem 2002;50:283-285.

59 Giwercman A, Lindenberg S, Kimber SJ, et al. Monoclonal antibody $43-9 \mathrm{~F}$ as a sensitive immunohistochemical marker of carcinoma in situ of human testis. Cancer 1990;65:1135-1142.

60 Marks A, Sutherland DR, Bailey D, et al. Characterization and distribution of an oncofetal antigen (M2A antigen) expressed on testicular germ cell tumours. Br J Cancer 1999;80:569-578.

61 Looijenga LH, Stoop H, de Leeuw HP, et al. POU5F1 (OCT3/4) identifies cells with pluripotent potential in human germ cell tumors. Cancer Res 2003;63: 2244-2250.

62 Looijenga LH, de Munnik H, Oosterhuis JW. A molecular model for the development of germ cell cancer. Int J Cancer 1999;83:809-814.

63 Chaganti RS, Houldsworth J. The cytogenetic theory of the pathogenesis of human adult male germ cell tumors. Review article. Apmis 1998;106:80-83; discussion 83-84.

64 Chaganti RS, Houldsworth J. Genetics and biology of adult human male germ cell tumors. Cancer Res 2000;60:1475-1482.

65 Grigor KM, Skakkebaek NE. Pathogenesis and cell biology of germ cell neoplasia: general discussion. Eur Urol 1993;23:46-53.

66 Bosl GJ, Ilson DH, Rodriguez E, et al. Clinical relevance of the $\mathrm{i}(12 \mathrm{p})$ marker chromosome in germ cell tumors. J Natl Cancer Inst 1994;86:349-355.

67 Rodriguez E, Mathew S, Mukherjee AB, et al. Analysis of chromosome 12 aneuploidy in interphase cells from human male germ cell tumors by fluorescence in situ hybridization. Genes Chromosomes Cancer 1992;5: 21-29.

68 Rodriguez E, Houldsworth J, Reuter VE, et al. Molecular cytogenetic analysis of i(12p)-negative human male germ cell tumors. Genes Chromosomes Cancer 1993;8:230-236.

69 Rodriguez S, Jafer O, Goker H, et al. Expression profile of genes from $12 p$ in testicular germ cell tumors of adolescents and adults associated with $\mathrm{i}(12 \mathrm{p})$ and amplification at 12p11.2-p12.1. Oncogene 2003;22: 1880-1891.

70 Kraggerud SM, Skotheim RI, Szymanska J, et al. Genome profiles of familial/bilateral and sporadic testicular germ cell tumors. Genes Chromosomes Cancer 2002;34:168-174.

71 Blough RI, Heerema NA, Ulbright TM, et al. Interphase chromosome painting of paraffin-embedded tissue in 
the differential diagnosis of possible germ cell tumors. Mod Pathol 1998;11:634-641.

72 Houldsworth J, Reuter V, Bosl GJ, et al. Aberrant expression of cyclin D2 is an early event in human male germ cell tumorigenesis. Cell Growth Differ 1997; 8:293-299.

73 Murty VV, Li RG, Houldsworth J, et al. Frequent allelic deletions and loss of expression characterize the DCC gene in male germ cell tumors. Oncogene 1994;9: 3227-3231.

74 Houldsworth J, Xiao H, Murty VV, et al. Human male germ cell tumor resistance to cisplatin is linked to TP53 gene mutation. Oncogene 1998;16:2345-2349.

75 Schneider DT, Schuster AE, Fritsch MK, et al. Genetic analysis of childhood germ cell tumors with comparative genomic hybridization. Klin Padiatr 2001;213: 204-211.

76 Schneider DT, Schuster AE, Fritsch MK, et al. Multipoint imprinting analysis indicates a common precursor cell for gonadal and nongonadal pediatric germ cell tumors. Cancer Res 2001;61:7268-7276.

77 Bussey KJ, Lawce HJ, Himoe E, et al. Chromosomes 1 and 12 abnormalities in pediatric germ cell tumors by interphase fluorescence in situ hybridization. Cancer Genet Cytogenet 2001;125:112-118.

78 Silver SA, Wiley JM, Perlman EJ. DNA ploidy analysis of pediatric germ cell tumors. Mod Pathol 1994;7: 951-956.

79 Jenderny J, Koster E, Borchers $\mathrm{O}$, et al. Interphase cytogenetics on paraffin sections of paediatric extragonadal yolk sac tumours. Virchows Arch 1996;428:53-57.

80 Stock C, Strehl S, Fink FM, et al. Isochromosome 12p and maternal loss of $1 \mathrm{p} 36$ in a pediatric testicular germ cell tumor. Cancer Genet Cytogenet 1996;91:95-100.

81 Stoop H, van Gurp R, de Krijger R, et al. Reactivity of germ cell maturation stage-specific markers in spermatocytic seminoma: diagnostic and etiological implications. Lab Invest 2001;81:919-928. 